\title{
Dependency Analysis Between Various Profit Measures and Corporate Total Assets for Visegrad Group's Business Entities
}

\author{
Lucia SVABOVA, Katarina VALASKOVA, Pavol DURANA, \\ Tomas KLIESTIK
}

University of Zilina, Faculty of Operation and Economics of Transport and Communications, Department of Economics, Univerzitna 1, 01026 Zilina, Slovakia, lucia.svabova@fpedas.uniza.sk, katarina.valaskova@fpedas.uniza.sk, pavol.durana@fpedas.uniza.sk, tomas.kliestik@fpedas.uniza.sk

\begin{abstract}
Background and Purpose: Models of identifying and predicting earnings management in companies by using accruals are in general based on the dependence between total assets of companies and various profit measures. In this paper, we focused on an initial dependency analysis between these business indicators in the Visegrad group's business entities. We explore the mentioned relationships, verify, and quantify the strength of the dependencies between earnings levels of companies (in terms of economic evaluation of the return on business capital in absolute terms) and the value of their total assets (i.e. business capital tied in the assets without its further classification and analysis).

Methodology: We use descriptive statistics as well as a correlation analysis based on the real business data on almost 300 thousand companies in the V4 countries from the Amadeus database, covering the period from 2013 to 2017. Finally, we use a comparative analysis to identify disproportion among the results that were found out for each of the analysed countries.

Results: The analysis showed that Slovak companies have the average values of profit measures and total assets comparable to Hungarian companies. Czech and Polish companies have several times higher average values of profit measures and also of total assets than Slovak and Hungarian companies. The analysis of the development of the profit measures and the total assets of the companies over the years showed significant differences across the four countries during the period covered by this study.

Conclusion: The analysis of relationships between total assets of the companies and their profit measures showed that the strength of these dependencies among countries is very similar, and over the years, these results did not change. The results of this study can be further used in the creation of the earnings management model in enterprises, both in Slovakia and in other V4 countries.
\end{abstract}

Keywords: profit measures; total assets; earnings management; correlation

\section{Introduction}

Earnings management (EM) is currently discussed but also controversial and at the same time very promising topic in the field of finance and financial management of companies (Stolowy and Breton, 2000). The main subject of this topic is corporate profits. Earnings management is a kind of management that uses accounting techniques to meet the executives' needs for earnings (Chen, 2010). When preparing an enterprise's financial statements, business managers have legal opportunities as well as the incentive to implement to a certain extent their own judgment and subjective estimates in order to satisfy their own needs and the needs of the company (Kral and Janoskova, 2015,

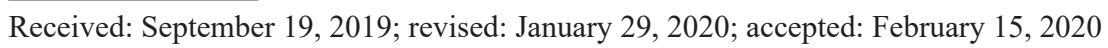


Kramarova et al., 2014). This consequently leads to opportunistic management reporting profits. Information gain value, therefore, becomes for users of financial statements questionable (Lev, 2018). These reasons are behind the fact that the topic of earnings management has become more prevalent in many companies and is in recent years in the interest of scientists and economists in several countries (Popescu Ljungholm, 2018).

The most reliable models of identifying and predicting earnings management are models of discretionary accruals (Beslic et al., 2015) Accordingly, the financial accounting literature has made efforts to identify the determinants of earnings management behaviour in various industries (Mellado-Cid et al., 2019). In Slovakia, no studies have been published directly on this topic yet and a similar situation is in neighbouring Czech Republic and Hungary. Our work in the future will lead to the creation of a complex model of earnings management for companies in Slovakia and also other countries, where we will deal with various earnings levels as model output variables and total assets as an input variable. This is why we focused in this study on companies in Visegrad Group (V4) countries and the main aim of this study is to explore relationships and verify dependencies between various earnings levels of companies and the value of total assets of the companies in V4. Finding the dependencies and analyzing the mutual relation between profits gained and corporate total assets may be helpful in determining the limitations of what can be perceived as manipulation with earnings in specific national environments. The contribution of the paper lies in the use of the real database on almost 300 thousand companies in the V4 countries. The main purpose of the study is to quantify the strength of the dependency between the earnings of the companies and their total assets and to analyze the significance of these relationships. This analysis is based on the use of statistical methods and procedures. Its output provides insight into the main statistical characteristics of the various profit levels and total assets of the companies over the years covered by this study, and mainly, the quantification of the strength of relationships among these companies' indicators.

Our study consists of four main parts. The introduction highlights the main aspects of the study and a literature review of the current state of this topic. The second part briefly describes the statistical methods used in this study and the data used for this analysis. The third part presents the results of the study. The conclusion summarizes the results and indicates further possible directions of the research in this field.

\section{Literature review}

As the first model to identify the presence of Earnings Management in companies, the Hepworth (1953) model is considered. The author of this study finds smoothing as a reasonable and wise action, serving managers to smooth their income by using specific means (Saeidi, 2012). Moreover, the author has documented various tactics that can be used to transfer net profit to subsequent accounting periods. But this study does not consider a way to detect this transferring of the profits. Among the first studies, focusing on the detection of earnings management in the company, belong for example the studies of Gordon (1964); Dopuch and Drake (1966); Archibald (1967). These studies are based on a time series. Gordon et al. (1966) were the first who used mathematical modelling for the testing of the balancing profit. As a breakthrough study on this issue, the study of Jones (1991) is considered. The author analysed the earnings management using a two-step model based on time series data. In the subsequent years, several authors tried to modify the model of Jones by supplementing, omitting or modification of the variables, for example, Key (1997), Kasznik (1999), McNichols (2000), Kothari et al. (2005).

Since then, the interest of scientists in this topic has grown significantly. Gim et al. (2019) examined, whether franchising as a firm characteristic causes any meaningful differences in the earnings management behaviour of restaurant firms. The results of their study show that franchise restaurants are generally more inclined towards earnings management, mainly during their growth phase. Mellado-Cid et al. (2019) studied the relationship between the stock options' volatility and real earnings management in the company. The authors hypothesised that earnings management cause uncertainty in the value of a firm's common stock and really found the association between them, especially in put options. The study of Liu et al. (2018) aimed at investigating the effects of short selling on a firm's executive compensation and earnings management. Their analysis showed that the executives of the short-selling firms justify their excess compensation by improving the pay-performance sensitivity, through the real earnings management. The authors found that there is a more significant change in real earnings management in short-selling firms. In the study of Darrough et al. (2017), the authors examine whether managers shift income-decreasing special items to discontinued operations. They found that managers really tend to classification-shift asset write-downs to discontinued operations. Jia and Zhou (2019) in their study empirically examined the effect of cross-listing on earnings management and its economic consequences in companies in China. They considered both accrual-based earnings management and real earnings management and the results of the study reveal that accrual-based earnings management can maintain debt contract efficiency and real earnings management plays a role in signalling better performance. Jacoby et al. (2016) in their study explored the relationship between corporate financial distress and earnings management using a sample of politically affiliated private firms in China and also 
examined the effects of political affiliation and regional development on this relation. Their findings suggest that financially distressed firms use earnings management more than financially healthy firms. They also found that political affiliation weakens the association between financial distress of the company and small positive earnings management.

In Slovakia, but also in the neighbouring Czech Republic and Hungary, this topic is in the scientific community still new. Some authors from Slovakia have mentioned earnings management in their studies, for example, Saxunova (2015), Vagner (2015), Paksiova (2017). But their studies are not dedicated to this issue and do not deal with it deeper. Similarly, in the Czech Republic, there are several studies that mention earnings management, for example, Prochazka (2017), Jiraskova and Molin (2015), but these do not focus deeply on the issue of earnings management. In Hungary, the situation is very similar. There are a few studies that mentioned earnings management, such as Markus et al. (1998), Olah et al. (2017a), Olah et al. (2017b), but these studies are not focused on earnings management directly. In Poland, the situation is quite different. In the past few years, several polish authors have been dealing with the topic of earnings management. For example, Lizinska and Czapiewski (2018) studied discretionary accruals in Polish companies and their correlation with subsequent long-term market value for initial public offerings made before the financial crisis. The authors consider their conclusions to be robust with respect to the latest innovations in proxies for the topic of earnings management. Di Narzo et al. (2018) in their study used data from France, Germany, Italy and the UK to investigate how the ability to detect earnings manipulations through accruals models are affected by the use of different industry classifications. Their analyses showed that enlarging the industry classification reduces the probability of discovering earnings manipulations.

\section{Methodology and data}

In this study, we focus on the analysis of different levels of corporate profits in the V4 countries and their relationship with the total assets of the company. In this relationship, the models of earnings management identification using the accruals are based (Fogarassy, 2018). The value of corporate assets points to the total capital strength of a company (absolute indicator); different levels of corporate profit used in the study are then the absolute expression of their profitability (absolute indicators).

For the analysis, we use data on real companies from the V4 from the Amadeus, a database of comparable financial information for public and private companies across Europe. Amadeus contains comprehensive information on around 21 million European companies (Bureau Van Dijk, 2019). Overall, the dataset used in this study contains data about 299,355 companies. The number of companies, included in the database, from individual countries of V4 is shown in the following table.

Table 2: Frequencies of companies in the database

\begin{tabular}{|l|r|r|}
\hline Country & Frequency & Percent \\
\hline Czech Republic & 34,970 & 11.7 \\
\hline Hungary & 177,756 & 59.4 \\
\hline Poland & 32,251 & 10.8 \\
\hline Slovakia & 54,378 & 18.2 \\
\hline Total & 299,355 & 100.0 \\
\hline
\end{tabular}

Source: Own elaboration

We have data on companies from 2013 to 2017, which was at the moment of writing this study the latest possible data from companies' financial statements. The database contains, among other characteristics of the companies, values of eight different profit measures ( 6 absolute indicators, 2 ratio indicators) and the value of total assets of companies. Although absolute indicators have limited explanatory power in the financial analysis (preference is given to ratio indicators) (Kicova and Kramarova, 2013), the primary identification of the relationship between assets and profit levels is a logical and de facto "gateway" for identifying earnings management. (Kramarova et al., 2020)

For variables, we use the following designation and method of calculation, shown in Table 2. In the table, we provide the calculation method as it is provided by the database Amadeus.

As a weakness of the Amadeus database, we consider the fact that it does not contain all the necessary data, or that the data it provides is very limited. Specifically, for example, it does not include data from all items in the profit and loss account of enterprises. This fact, for example, limited the explanatory power of our findings in case of the indirect relationship between the assets and the identified loss resulting from financial activities in case of some countries (see Table 6). We believe that this may be related to using of credit forms of financing i.e. with the interest payment process (de facto with the price of credit forms of financing and the rate of their use in overall process of assets financing) or with reported foreign exchange losses. However, despite the weaknesses of the Amadeus database, it is very high quality and extensive database. We consider the data there to be very valuable, as data from several countries allow international comparisons of companies or the creation of international models.

In the first step of processing the database, we focused on the existence of outliers that might skew the results of 
Table 2: Variables in the database

\begin{tabular}{|c|c|}
\hline Variable & Label \\
\hline PLBT & Profit $/$ loss before tax $=$ Operating profit + financial profit \\
\hline PL & $\begin{array}{l}\text { Profit/loss for period }=\text { Net income for the Year. Before deduction of Minority interests if } \\
\text { any (Profit after taxation }+ \text { Extraordinary and other profit). }\end{array}$ \\
\hline PLAT & Profit $/$ loss after tax $=$ Profit before taxation - Taxation \\
\hline OPPL & $\begin{array}{c}\text { EBIT (Earnings before interest and taxes, Operating profit/loss) = All operating revenues - } \\
\text { all operating expenses (Gross profit-Other operating expenses) }\end{array}$ \\
\hline EBTA & $\begin{array}{l}\text { EBITDA (Earnings before interest, taxes, depreciation and amortization charges) }=\text { Opera- } \\
\text { ting profit }+ \text { Depreciation }\end{array}$ \\
\hline FIPL & $\begin{array}{c}\text { Finacial profit } / \text { loss }=(\text { Financial revenue-Financial expenses })=(\text { All financial revenues such } \\
\text { as interest, incomes from shares, etc. })-(\text { All financial expenses such as interest charges, } \\
\text { write-off financial assets })\end{array}$ \\
\hline ETMA & EBIT margin $=($ EBIT $/$ Operating revenue $) * 100$ \\
\hline EBMA & EBITDA margin $=$ EBITDA $/$ Operating revenue) $* 100$ \\
\hline TA & Total assets $=$ Total assets (Fixed assets + Current assets) \\
\hline
\end{tabular}

Source: Own elaboration

the analysis. As our database is a multidimensional set, we focused on multivariate outliers and to identify them, we chose the Mahalanobis distance. This metric measures the multidimensional distance of each observation from the group centroid. The advantage of Mahalanobis distance is its insensitivity to the change in the scale of variables. According to Tabachnic and Fidell (2007), the procedure for detecting multidimensional extreme values is as follows. We will use a linear regression method, where all variables that we have in the database, are used as explanatory variables. Based on this, we calculate the value of Mahalanobis distance for each statistical unit and its realization of individual independent variables. To verify this, we create the variable $\mathrm{P}_{-} \mathrm{MD}$ defined using the $\chi^{2}$-distribution and the Mahalanobis distance by

$$
P_{M D}=1-C D F_{C h i s q}(M D, D f),
$$

where $\mathrm{CDF}_{\text {Chisq }}$ is the cumulative distribution function of the random variable with $\chi^{2}$-distribution, Df is the number of independent variables in the linear regression model and MD is the Mahalanobis distance defined for i-th observation by

$$
M D_{i}=\sqrt{\left(x_{i}-\bar{x}\right)^{\prime} s^{-1}\left(x_{i}-\bar{x}\right)} .
$$

where: $x_{i}$ is the $i$-th statistical unit values vector, $\bar{x}$ is a sample centroid, that is, a vector of sample means, $\mathrm{s}$ is a sample covariance matrix. The $\mathrm{P}_{\mathrm{MD}}$ variable is used to identify multivariate outliers. If it holds

$$
P_{M D}<0.001
$$

this indicates that the unit is a multi-dimensional outlier with respect to the other units in the file. A value of 0.001 is recommended by Tabachnick and Fidell (2013). By sequencing the statistical file according to the decreasing Mahalanobis distance, we can see whether some cases tend to appear as multivariate outliers because its distance values are higher than with other companies. Companies that are based on this analysis proved to be multivariate outliers, were subsequently excluded from our database from further analysis. These multivariate outliers were examined in each group of companies, defined by the country.

To characterize groups of companies in every of V4 countries, statistical descriptive characteristics will be used (Popp et al., 2018). For each variable, we list the mean, standard deviation, median, minimum and maximum values. These characteristics can be used to compare groups of companies in individual Visegrad countries and also to monitor the development of the value of the various profit measures of companies over the years (Olah et al., 2019). To compare the means of profit measures of the companies and also means of total assets during the years, we conducted Friedman's nonparametric test (Bin et al., 2018). This test is an alternative to the ANOVA test 
for related samples. Friedman's test is also an alternative to the Wilcoxon's test. Wilcoxon's test serves in case of two related samples and Friedman's test is suitable if there are at least 3 related samples. This test detects whether the median values of profit measures and also total assets of companies in individual years (and in the V4 countries) differ significantly.

To analyze the dependencies between profit measures and total assets of the companies, we use Pearson's correlation coefficient, which is a measure of the linear relationship between two quantitative variables. In determining the degree of dependence, we will proceed from the following scale (Ratner, 2009):

- weak correlation, if $0<|\mathrm{r}|<0.3$,

- $\quad$ moderate correlation, if $0.3 \leq|\mathrm{r}|<0.7$,

- $\quad$ strong correlation, if $0.7 \leq|\mathrm{r}|<1$.

In addition to the value of the correlation coefficient, we always list the p-value of the test of its statistical significance, based on which we identify the correlations between total assets and various profit measures that are statistically significant and the ones that are not (Valaskova et al., 2018).

\section{Results}

Analysis of the presence of multivariate outliers in files has shown that some enterprises are significantly different from other enterprises in a given country by their values. We defined the variable $\mathrm{P}_{\mathrm{MD}}$ according to equation (1), while the Mahalanobis distance was calculated according to (2). Subsequently, under rule (3), we have identified for every company whether it is considered to be a multivariate outlier or not. This analysis showed the numbers of multivariate outliers in each country (Table 3 ). The percentage of excluded companies in each country is between $2.1 \%$ and $3.9 \%$.

After this analysis, 291,426 companies remained in our database, 7,934 companies were marked as multivariate outliers. Outlying companies account for $2.72 \%$ of all companies. These companies were excluded from further analysis.

In the next step, we focused on the descriptive characteristics of various profit measures as well as their total assets. These characteristics were calculated separately for companies in each country and separately for each of the years 2013 to 2017. For brevity, we present the characteristics of all the variables of companies in individual countries in 2017 (Table 4).

Next, we compared individual profit measures, as well as total assets of the companies, over the years 2013 to 2017 using available data. We verified the existence of significant differences between the median values of variables using the Friedman test with the null hypothesis that there were no significant differences between the median val- ues of variables over the years. Table 5 shows an example of the output of Friedman's test for the total assets of the companies in Slovakia.

We performed this test for each of the profit measures as well as for total assets. The results of all tests in all countries and for all variables are the same: the mentioned zero hypothesis was rejected, so that values of profits and total assets of companies in V4 countries have changed significantly over the years.

Furthermore, we analysed the relationship between profit measures and the total assets of the companies. The strength of the linear dependence between the individual profit measure and the total assets of the companies was quantified using the Pearson's correlation coefficient (Tretyak, 2018). Moreover, the value of the correlation coefficient is always supplemented by the p-value of its significance test with the null hypothesis that this relationship is statistically insignificant. The values of the correlation coefficients together with the $\mathrm{p}$-values of their significance tests are shown in Table 6.

For brevity, we again present only outputs from this analysis from 2017. For the other years included in the study, the results of the correlation analysis are very similar. We used color highlighting of the correlation degrees in the table. Using the red data bars we marked the comparison of the correlation strengths for each profit measure (i.e. the correlation coefficient between total assets and the given profit measure among the V4 countries is compared in each row of the table). In this way, we compared individual profit measures among the countries. At the same time, we used cell coloring and font colors to indicate the strength of the dependence. We used a three-stage scale, where: the yellow color indicates a weak linear dependence (i.e., a correlation coefficient of $(-0.3 ; 0.3)$ ); green indicates moderate dependence (i.e. correlation coefficient $(0,3 ; 0,8)$ or $(-0.8 ;-0.3)$, respectively) and finally, red indicates strong dependence (i.e. correlation of $(0.8 ; 1)$, or $(-1 ;-0.8))$. In this way, we can immediately visually determine the strength of dependence between a given profit measure and the total assets of companies in a given country.

According to the p-value of the significance tests of the correlation coefficient (always the second row of the profit indicator in Table 6 above), we can see that the linear dependence between EBITDA margin and total assets in 2017 is insignificant. Also, the linear relationship between EBIT margin and total assets is insignificant for Slovak companies, but according to other correlation coefficients we see that even in other V4 countries, linear relationships in this pair of variables are weak. Other correlations are statistically significant. Depending on the values and signs of the correlation coefficients themselves, we can assess the strength of linear relationships between profit measure and total assets, as well as the direction of this dependence.

From 2013 to 2016, which we also analysed in this study, the results of the correlation analysis are very similar. For the sake of brevity, we do not list them in full. 
Table 3: Frequencies of multivariate outliers

\begin{tabular}{|c|c|c|c|c|c|c|}
\hline \multirow{2}{*}{ Country } & \multicolumn{2}{|c|}{ non-outliers } & \multicolumn{2}{c|}{ outliers } & \multicolumn{2}{c|}{ Total } \\
\cline { 2 - 7 } & Frequency & Percent & Frequency & Percent & Frequency & Percent \\
\hline Czech Republic & 33,620 & 96.1 & 1,350 & 3.9 & 34,970 & 100.0 \\
\hline Hungary & 173,982 & 97.9 & 3,774 & 2.1 & 177,756 & 100.0 \\
\hline Poland & 31,052 & 96.3 & 1,199 & 3.7 & 32,251 & 100.0 \\
\hline Slovakia & 52,767 & 97.0 & 1,611 & 3.0 & 54,378 & 100.0 \\
\hline
\end{tabular}

Source: Own elaboration

Table 4: Characteristics of profit measures (in thousand EUR) of companies in 2017 in V4 group countries

\begin{tabular}{|c|c|c|c|c|c|c|c|c|c|c|}
\hline \multicolumn{2}{|c|}{ 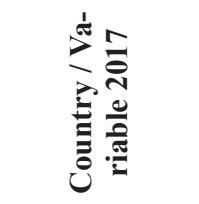 } & 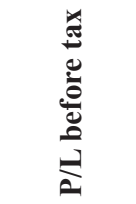 & 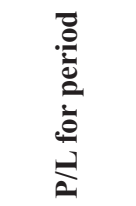 & 氞 & 皇 & 氙 & 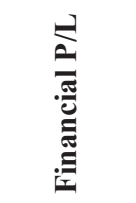 & 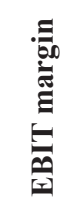 & 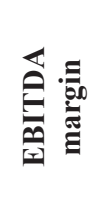 & 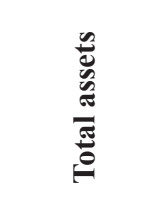 \\
\hline \multirow{4}{*}{ 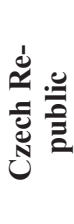 } & Min & -23458.3 & -23444.4 & -23444.4 & -24138.8 & -22085.7 & -24006.3 & -93.1 & -99.6 & 0.0 \\
\hline & Max & 170884.7 & 138677.5 & 138677.5 & 131839.4 & 215999.5 & 39045.3 & 100.0 & 97.3 & 1037890.0 \\
\hline & Mean & 264.1 & 214.0 & 213.7 & 281.0 & 444.2 & -16.9 & 15.4 & 7.9 & 3898.7 \\
\hline & St. Dev & 1432.6 & 1184.5 & 1184.4 & 1311.5 & 1901.2 & 372.9 & 21.0 & 17.1 & 12901.8 \\
\hline \multirow{4}{*}{ 胥 } & Min & -25561.5 & -25562.9 & -25562.9 & -9058.6 & -8446.2 & -25546.2 & -99.2 & -100.0 & 0.0 \\
\hline & Max & 431594.5 & 408991.0 & 408991.0 & 444994.2 & 515849.1 & 19948.0 & 100.0 & 99.6 & 546026.1 \\
\hline & Mean & 51.5 & 47.4 & 47.4 & 52.7 & 75.4 & -1.1 & 14.4 & 8.5 & 577.5 \\
\hline & St.Dev & 1274.3 & 1221.4 & 1221.4 & 1272.9 & 1543.0 & 106.6 & 23.2 & 22.3 & 3101.3 \\
\hline \multirow{4}{*}{ 를 } & Min & -19446.1 & -20380.0 & -20380.0 & -29470.5 & -15492.8 & -24746.3 & -89.3 & -99.1 & 1.2 \\
\hline & Max & 106013.2 & 83675.7 & 82890.3 & 109203.5 & 377481.5 & 46636.7 & 99.7 & 91.4 & 14449806.6 \\
\hline & Mean & 388.5 & 330.3 & 330.2 & 410.1 & 628.4 & -21.5 & 9.1 & 5.8 & 6471.1 \\
\hline & St. Dev & 1593.1 & 1354.5 & 1337.6 & 1590.8 & 3072.4 & 452.8 & 13.5 & 12.0 & 86371.2 \\
\hline \multirow{4}{*}{ 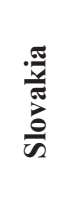 } & Min & -13866.9 & -13869.8 & -13869.8 & -13731.0 & -4100.9 & -5244.4 & -96.4 & -99.9 & 0.1 \\
\hline & Max & 101206.0 & 79512.0 & 79512.0 & 98113.0 & 156003.0 & 9462.1 & 100.0 & 98.7 & 1578716.0 \\
\hline & Mean & 64.0 & 47.5 & 47.6 & 71.9 & 126.8 & -7.8 & 16.8 & 7.4 & 1131.3 \\
\hline & St.Dev & 638.5 & 483.8 & 484.4 & 636.8 & 910.9 & 80.8 & 22.1 & 19.7 & 8397.9 \\
\hline
\end{tabular}

Source: Own elaboration

Table 5: Friedman's test for homogeneity of medians of total assets of companies in Slovakia

\begin{tabular}{|c|c|c|c|}
\hline \multicolumn{4}{|c|}{ Hypothesis Test Summary } \\
\hline Null Hypothesis & Test & Sig. & Decision \\
\hline $\begin{array}{c}\text { The distributions of Total assets 2017, Total assets 2016, } \\
\text { Total assets 2015, Total assets 2014 and Total assets 2013 are } \\
\text { the same }\end{array}$ & $\begin{array}{c}\text { Related Samples Friedman's } \\
\text { Two-Way Analysis of Variance by } \\
\text { Ranks }\end{array}$ & $\begin{array}{c}0.000 \\
\text { Reject the null } \\
\text { hypothesis }\end{array}$ \\
\hline
\end{tabular}

Source: Own elaboration 
Table 6: Correlations of profit measures and total assets of the V4 enterprises in 2017

\begin{tabular}{|c|c|c|c|c|c|c|}
\hline \multirow{2}{*}{ Variable 2017 } & Correlation & $\begin{array}{c}\text { Czech } \\
\text { Republic }\end{array}$ & Hungary & Poland & Slovakia \\
\cline { 3 - 6 } & \multicolumn{3}{|c|}{ Correlation with Total assets 2017 } \\
\hline \multirow{2}{*}{ P/L before tax } & Pearson Correlation & 0.686 & 0.463 & 0.257 & 0.750 \\
\cline { 2 - 6 } & p-value & 0.000 & 0.000 & 0.000 & 0.000 \\
\hline \multirow{2}{*}{ P/L for period } & Pearson Correlation & 0.677 & 0.453 & 0.220 & 0.773 \\
\cline { 2 - 6 } & p-value & 0.000 & 0.000 & 0.000 & 0.000 \\
\hline \multirow{2}{*}{ P/L after tax } & Pearson Correlation & 0.677 & 0.453 & 0.216 & 0.773 \\
\cline { 2 - 6 } & p-value & 0.000 & 0.000 & 0.000 & 0.000 \\
\hline \multirow{2}{*}{ EBIT } & Pearson Correlation & 0.705 & 0.504 & 0.100 & 0.749 \\
\cline { 2 - 6 } & p-value & 0.000 & 0.000 & 0.000 & 0.000 \\
\hline \multirow{2}{*}{ EBITDA } & Pearson Correlation & 0.811 & 0.655 & 0.844 & 0.874 \\
\cline { 2 - 6 } & p-value & 0.000 & 0.000 & 0.000 & 0.000 \\
\hline \multirow{2}{*}{ Finacial P/L } & Pearson Correlation & 0.164 & -0.039 & 0.560 & -0.018 \\
\cline { 2 - 6 } & p-value & 0.000 & 0.000 & 0.000 & 0.000 \\
\hline \multirow{2}{*}{ EBIT margin } & Pearson Correlation & 0.034 & 0.018 & 0.023 & 0.000 \\
\cline { 2 - 6 } & p-value & 0.000 & 0.000 & 0.000 & 0.994 \\
\hline \multirow{2}{*}{ EBITDA margin } & Pearson Correlation & 0.032 & 0.014 & 0.004 & 0.000 \\
\cline { 2 - 6 } & p-value & 0.000 & 0.000 & 0.446 & 0.912 \\
\hline
\end{tabular}

Source: Own elaboration

\section{Discussion and conclusion}

In the study, we focus on the analysis of various profit measures of companies in Visegrad group countries in the years 2013-2017. We examined the characteristics of individual profit measures, their differences within V4 countries, their evolution over time and their relationship with total assets of the company. We based on generally known premise that the effective use of a capital tied in company assets, in other words, the effective use of assets, is a prerequisite for generating corporate profits, while corporate profits we quantified mainly as absolute values of the various profit measures (e.g. EAT, EBT, EBIT, EBITDA etc.). The findings point to the fact that the greatest capital strength (on average) was characteristic for Polish companies in all analysed years. On the contrary, the smallest amount of capital tied in assets was found in the case of Hungarian enterprises, again for all periods analysed.

The analysis of average values of profit measures among the countries showed that Slovak companies have all these values comparable to Hungarian companies and at the same time several times lower than Polish and Czech companies. Polish companies achieve the highest average profit measures. Similar results were for the total assets of the companies, where the lowest average value is achieved by Hungarian companies, followed by Slovak companies. Again, the companies in the Czech Republic and Poland have several times higher average values of total assets. Based on this we deduce that on average companies in the Czech Republic and Poland are characterized by a higher capital strength than companies in Slovakia and Hungary (the origin of capital in terms of ownership was not examined in the study). We also looked at whether the individual profit measures and the total assets of the companies were significantly different over the years included in this study. Using Friedman's test, we found that all of the companies' profit measures differed significantly across the four countries during the whole period 20132017 included in this study.

Subsequently, the analysis of relationships between total assets of the companies and individual profit measures showed that the strength of dependence among the V4 countries is very similar, and over the years, these results did not change. Total assets of the companies are overwhelmingly the most correlated with EBIT, EBITDA and then with Profit / loss before tax, Profit / loss for period and Profit / loss after tax. Negative correlation is only between Financial profit / loss and total assets of companies in Hungary and Slovakia, although according to the value of the correlation coefficient, it is a very weak correlation. However, this negative correlation is closely related to the fact that the mean values of this variable were negative for companies in all four countries (Table 4). This may be caused by the character of the financial profit/loss, which 
is calculated as a difference between the financial revenues (e.g. sale of securities, financial operations) and financial expenses (e.g. paid interests for loans, exchange losses). Due to the underdeveloped capital market of most of the V4 countries, it is evident that in most companies the financial expenses exceed the financial revenues causing the negative mean values of this variable. However, like any other profitability ratio, also the financial profit/loss provides important information as it quantifies the level of financial profit an enterprise may generate considering the level of corporate total assets. Thus, the impact of the financial profit/loss indicator on the sign of correlation with the Total assets of the companies should be more focused on further research.

In the case of Slovak companies, except the relationship between Financial profit / loss and EBIT margin with Total assets, there are always strong correlations between individual profit measure and total assets of the companies. The weakest correlated are profit measures and Total assets of the companies in Poland.

If we focus on the strength of dependence between individual profit measures and Total assets, we can conclude that total assets have the following linear relationship with profit measures:

\section{- in the Czech Republic:}

- a weak linear relationship with Financial profit / loss, EBIT margin and EBITDA margin;

- a moderate linear relationship with Profit / loss before tax, Profit / loss for period and Profit / loss after tax;

- a strong linear relationship with EBIT and EBITDA.

- in Hungary:

- a weak linear relationship with Financial profit / loss, EBIT margin and EBITDA margin;

- a moderate linear relationship with the other profit measures.

- in Poland:

- a moderate linear relationship with Financial profit / loss;

- a strong linear relationship with EBITDA;

- a weak linear relationship with the others.

- in Slovakia:

- a weak linear relationship with Financial profit / loss, EBIT margin and EBITDA margin;

- a strong linear relationship with the other profit measures.

If we compare between the countries, we find that in the case of significantly correlated profit measures, the strongest dependencies are found in Slovakia, followed by the second Czech Republic. We would call these relationships very similar and indicate stronger to moderate dependencies between total assets and other profit measures (with the exception of the last two/three profit mea- sures in Table 5, for which a linear relationship is very weak). Slightly weaker relationships were quantified in Hungarian enterprises and weakest are the correlations in Polish enterprises. In this comparison, Poland is the only country that differs from the other three V4 countries, and this applies to the Total assets of enterprises with all profit measures except EBITDA. This result follows the conclusions in Svabova et al. (2019), where it was found that the average EBITDA of enterprises, except from the couple Czech Republic - Poland, differs significantly in each pair of V4 countries, which also could have an impact on our differences in correlations with the Total assets of corporations. The mentioned study also found that in the Financial profit/loss, except for the couple Poland - Slovakia, the average values are not significantly different across countries. Again, this may affect the strength of the relationship of this profit measure with the total assets of enterprises identified in this study. In the case of the Financial profit/loss, this correlation is similar across countries, with the exception of Polish companies. Concretely, in the case of the Financial profit/loss measure, Polish companies show the strongest (namely, moderate and the only one positive) correlation with total assets. This is followed by Hungarian companies where this relationship is weak and indirect. In this case, the Czech and Slovak companies achieve also similar results, where the relationship is very weak and indirect. From this mathematical measure of dependence between financial profit/loss and total assets, it can be concluded that a change in one indicator has only a small (negative) effect on the change in the other. However, it should be borne in mind, that the Pearson correlation coefficient is only a measure of the linear dependence between variables. In this case, the dependence may be of a different, more complex type, which also follows from the economic interpretation of the profit measures.

The source for these similarities and also differences among the values of earning levels of the companies in V4 countries arises not only from the economic situation in these companies but also from the economic situation in the countries. Recalling the main indicators of the V4 countries, for example, the annual rates of change in GDP in 2017 were similar in all V4 countries, varying from 3.4 $\%$ in Slovakia to $4.6 \%$ in Poland. Moreover, the distribution of gross value added by the section is very similar in all four of these countries. The annual rate of change in the volume of industrial production and volume of retail trade turnover was also similar in 2017. The volume of export and import was very similar in Slovakia and Hungary and also in the Czech Republic and Poland, the volume of import was very similar (Main Indicators of the Visegrad Group Countries, 2018) The difference of Polish enterprises from other countries can also be partly explained by the fact that in Poland the publication of accounting data is voluntary for enterprises. Thus, only those enterprises that voluntarily provided this data are included in the sample, not all enterprises, as in the other three countries. The 
calculated average values, and related other values, may, therefore, be biased by the effect of this self-selection.

All the results described were interpreted from the values calculated from the 2017 indicators. Similarly as in the year 2017, in the years 2013 to 2016, which we also analyzed in this study, the correlation analysis showed that the Total assets of the company are the weakest correlated with Financial profit / loss, EBIT margin and EBITDA margin. At the same time, the weakest correlation of profit measures with Total assets are mainly in Polish companies.

To summarize, all the results obtained from the characteristics of individual profit measures as well as total assets, the comparison of their values over the years and the correlation analysis between profit measures and total assets will be further used for the development of an econometric model of dependence, showing the connection between variables and for the creation of the earnings management model in enterprises, both in Slovakia and in other V4 countries.

One of the limitations of the study is given by the recording and recalculating policy of the financial indicators in the Amadeus database - among the V4 countries, only Slovakia uses Euros as the official currency. Other countries, Poland, Hungary, and the Czech Republic still use their national currencies (zloty, forint, and Czech crowns). The values are converted into Euros using the exchange rate for the conversion. However, this exchange rate has changed over the years. The year-on-year comparison of absolute rates is therefore also affected by this exchange rate and its changes over the years, which was not taken into account when determining the significance of the differences in this study. At the same time, we consider the weakness of this study to be the fact that in the case of correlation analysis, we did not take into account the existence of relationships between individual profit measures. In our next study, we would like to focus on the relationships between individual variables and then the relationships between total assets and profit measures of the companies quantified using partial coefficients of multiple correlation. Also, the negative (indirect) result of the linear relationship between total assets and Financial profit / loss should be further examined.

\section{Acknowledgement}

This research was financially supported by the Slovak Research and Development Agency - Grant NO. APVV-170546: Variant complex model of Earnings management in conditions of Slovak republic as an essential tool of the market uncertainty.

\section{Literature}

Archibald, T. R. (1967). The Return to Straight-Line Depreciation: An Analysis of a Change in Accounting Method. Journal of Accounting Research, 5, 164-180. http://doi.org/10.2307/2489918

Beslic, I., Beslic, D., Jaksic, D., \& Andric, M. (2015). Testing the models for detection of earnings management. Industrija, 43(3), 55-79. http://doi.org/10.5937/industrija43-8035

Bin, L., Chen, D.-H., \& Hasanatunnisa, S. (2018). The Earnings-Return Association of Family and Non-Family Indonesian Firms: An Empirical Study. Economics, Management, and Financial Markets, 13(2), 56-69. http://doi.org/10.22381/emfm13220184

Bureau Van Dijk (2019). Amadeus. Retrieved September 11, 2019, from https://www.bvdinfo.com/en-gb/ our-products/data/international/amadeus

Chen, T. (2010). Analysis on accrual-based models in detecting earnings management. Lingnan Journal of Banking, Finance and Economics, 2(1). Retrieved from http://commons.ln.edu.hk/ljbfe/vol2/iss $1 / 5$

Darrough, M., Lee, Y. G., \& Oh, H. I. (2017). Classification shifting within non-recurring items. Asia-Pacific Journal of Accounting \& Economics, 26(3), 185-206. http://doi.org/10.1080/16081625.2017.1392877

Di Narzo, A. F., Freo, M., \& Mattei, M. M. (2018). Estimating accruals models in Europe: industry-based approaches versus a data-driven approach. Economic Research-Ekonomska Istraživanja, 31(1), 37-54. http://doi.org/10.1080/1331677x.2017.1421991

Dopuch, N., \& Drake, D. F. (1966). The Effect of Alternative Accounting Rules for Nonsubsidiary Investments. Journal of Accounting Research, 4, 192-219. $\mathrm{http} / / /$ doi.org/10.2307/2490182

Fogarassy, C., Neubauer, E., Mansur, H., Tangl, A., Oláh, J., \& Popp, J. (2018). The main transition management issues and the effects of environmental accounting on financial performance - with focus on cement industry. Administratie si Management Public, (31), 52-66. http://doi.org/1024818/amp/2018.31-04

Gim, J., Choi, K., \& Jang, S. (Shawn). (2019). Do franchise firms manage their earnings more? Investigating the earnings management of restaurant firms. International Journal of Hospitality Management, 79, 70-77. http://doi.org/10.1016/j.ijhm.2018.12.013

Gordon, M. J. (1964). Postulates, principles and research in accounting. The Accounting Review, 39(2), 251-263.

Gordon, M. J., Horwitz, B. N., \& Meyers, P. T. (1966). Accounting Measurements and Normal Growth of the Firm. In R. K. Jaedicke, Y. Ijiri, O. Nielsen (Eds.), Research in Accounting Measurement (pp. 221-231). Madison: American Accounting Association.

Hungarian Central Statistical $\mathrm{O} \neg$ ffice. (2018). Main indicators of the Visegrad group countries. V4 Connects. Retrieved March 17, 2019, from https://www.czso.cz-/ documents/10180/80650655/main_indicators_of_the 
visegrad_group_countries.pdf?fbclid $=$ IwAR2ZvTxeB3CkGL392nqekiPsp4041RfI1_hhrnNZWdHpEDeHvLTcGCKH314

Jacoby, G., Li, J., \& Liu, M. (2016). Financial distress, political affiliation and earnings management: the case of politically affiliated private firms. The European Journal of Finance, 25(6), 508-523.

http://doi.org/10.1080/1351847x.2016.1233126

Jia, Q., \& Zhou, J. (2019). The impact of cross-listing on earnings management and its economic consequence: evidence from China. Asia-Pacific Journal of Accounting \& Economics, 1-21.

http://doi.org/10.1080/16081625.2019.1600414

Jiraskova, S., \& Molin, J. (2015). IFRS Adoption for Accounting and Tax Purposes: An Issue Based on the Czech Republic as Compared with Other European Countries. Procedia Economics and Finance, 25, 5358. http://doi.org/10.1016/s2212-5671(15)00712-1

Jones, J. J. (1991). Earnings Management during Import Relief Investigations. Journal of Accounting Research, 29(2), 193-228. http://doi.org/10.2307/2491047

Kasznik, R. (1999). On the Association between Voluntary Disclosure and Earnings Management. Journal of Accounting Research, 37(1), 57-81. http://doi.org/10.2307/2491396

Key, K. G. (1997). Political cost incentives for earnings management in the cable television industry. Journal of Accounting and Economics, 23(3), 309-337. http://doi.org/10.1016/s0165-4101(97)00012-8

Kothari, S. P., Leone, A. J., \& Wasley, C. E. (2005). Performance matched discretionary accrual measures. Journal of Accounting and Economics, 39(1), 163-197. http://doi.org/10.1016/j.jacceco.2004.11.002

Kral, P., \& Janoskova, K. (2015). Condition of Acceptability of Project Risk in Management of the Project Portfolio. In Globalization and its socio-economic consequences, 15th Scientific International Conference, 7th-8th October 2015 (pp. 345-352). Zilina, Slovakia: EDIS - University of Zilina.

Kicova, E., \& Kramarova, K. (2013) Možnosti použitia finančnej analýzy $\mathrm{v}$ podnikoch autobusovej dopravy [Possibilities of using financial analysis in the bus transport companies]. In Financial management of firms and financial institutions, 9th International Scientific Conference, 9th-10th September 2013. Ostrava, Czech Republic: VŠB - Technická univerzita.

Kramarova, K., Gregova, E., \& Cisko, S. (2014). Changes in the corporate tax in Slovakia - tax license. Business and Management-Spausdinta, 263-271.

http://doi.org/10.3846/bm.2014.033

Kramarova, K., \& Valaskova, K. (2020). Application of Chosen Fraudulent Detection Technique in the Slovak Business Environment. SHS Web of Conferences, 74(2020).

https://doi.org/10.1051/shsconf/20207401007

Lev, B. (2018). The deteriorating usefulness of financial report information and how to reverse it. Accounting and Business Research, 48(5), 465-493. http://doi.org/10.1080/00014788.2018.1470138

Liu, F., Du, J., \& Bian, C. (2018). Don't Touch My Cheese: Short Selling Pressure, Executive Compensation Justification, and Real Activity Earnings Management. Emerging Markets Finance and Trade, 55(9), 19691990. http://doi.org/10.1080/1540496x.2018.150167 5

Lizinska, J., \& Czapiewski, L. (2018). Towards Economic Corporate Sustainability in Reporting: What Does Earnings Management around Equity Offerings Mean for Long-Term Performance? Sustainability, 10(12), 4349. http://doi.org/10.3390/su10124349

Markus, A., \& Vancza, J. (1998). Product Line Development with Customer Interaction. CIRP Annals, 47(1), 361-364.

http://doi.org/10.1016/s0007-8506(07)62851-0

Mellado-Cid, C., Jory, S. R., \& Ngo, T. N. (2019). Options trades, short sales and real earnings management. Accounting and Business Research, 49(4), 400-427. http://doi.org/10.1080/00014788.2019.1573655

McNichols, M. F. (2000). Research design issues in earnings management studies. Journal of Accounting and Public Policy, 19(4-5), 313-345. http://doi.org/10.1016/s0278-4254(00)00018-1

Olah, J., Bai, A., Karmazin, G., Balogh, P., \& Popp, J. (2017a). The Role Played by Trust and Its Effect on the Competitiveness of Logistics Service Providers in Hungary. Sustainability, 9(12), 2303. http://doi.org/10.3390/su9122303

Olah, J., Karmazin, G., Peto, K., \& Popp, J. (2017b). Information technology developments of logistics service providers in Hungary. International Journal of Logistics Research and Applications, 21(3), 332-344. http://doi.org/10.1080/13675567.2017.1393506

Oláh, J., Kovács, S., Virglerova, Z., Lakner, Z., Kovacova, M., \& Popp, J. (2019). Analysis and Comparison of Economic and Financial Risk Sources in SMEs of the Visegrad Group and Serbia. Sustainability, 11(7), 1853. http://doi.org/10.3390/su11071853

Paksiova, R. (2017). The Critical Analysis of Profit for its Allocation Decision-Making. Scientific Annals of Economics and Business, 64(s1), 41-56.

http://doi.org/10.1515/saeb-2017-0039

Popescu Ljungholm, D. (2018). Sharing Economy, Regulatory Arbitrage, and Urban Governance: How City Space Shapes Economic Growth and Innovation. Geopolitics, History, and International Relations, 10(1), 174-180. http://doi.org/10.22381/ghir10120189

Popp, J., Olah, J., Machova, V., \& Jachowicz, A. (2018). Private equity market of the Visegrad group. Ekonomicko-manazerske spektrum, 12(1), 1-15. http://doi.org/10.26552/ems.2018.1.1-15

Prochazka, D. (2017). Specifics of IFRS Adoption by Central and Eastern European Countries: Evidence from Research. Scientific Annals of Economics and Business, 64(1), 59-81.

http://doi.org/10.1515/saeb-2017-0005

Ratner, B. (2009). The correlation coefficient: Its values range between $+1 /-1$, or do they? Journal of Targeting, 
Measurement and Analysis for Marketing, 17(2), 139142, http://doi.org/10.1057/jt.2009.5

Saeidi, P. (2012). The Relationship between Income Smoothing and Income Tax and Profitability Ratios in Iran Stock Market. Asian Journal of Finance \& Accounting, 4(1), 46-51.

http://doi.org/10.5296/ajfa.v4i1.790

Saxunova, D. (2015). Pitfalls of the proposal for a new lease OFRS standard. In Hradec Economic Days, February 3rd and 4th, 2015 (pp. 158-173). Hradec Králové, Czech Republic: University of Hradec Králové.

Siekelova, A., Kovacova, M., Adamko, P. \& Stehel, V. (2019). Profit Management as an Instrument for SMEs Developing: the Case for Slovakia. Marketing and Management of Innovations, 3, 285-296http://doi.org/10.21272/mmi.2019.3-22

Stolowy, H., \& Breton, G. (2000). A Review of Research on Accounts Manipulation. In the 23rd Annual Congress of the European Accounting Association, March 29-31, 2000.

Svabova, L., Adamko, P. \& Popescu, G. H. (2019). The Analysis of Various Earnings Levels in Visegrad Group Companies. In Education Excellence and Innovation Management through Vision 2020, 33rd International-Business-Information-Management-Association Conference, 10th-11th April 2019 (pp. 2046-2054). Granada, Spain: Int business information management assoc-IBIMA.

Tabachnick, B. G., \& Fidell, L. S. (2007). Using Multivariate Statistics. Boston, MA: Allyn \& Bacon/Pearson Education.

Tretyak, V. (2018). Economic performance assessment for agricultural market in a region: Evidence from Russia. Ekonomicko-manazerske spektrum, 12(1), 83-93. http://doi.org/10.26552/ems.2018.1.83-93

Vagner, L. (2015). Controlling as an international economic tool. In Globalization and its socio-economic consequences, 15th Scientific International Conference, 7th-8th October 2015 (pp. 829-833). Zilina, Slovakia: EDIS - University of Zilina.

Valaskova, K., Kliestikova, J., \& Krizanova, A. (2018). Consumer Perception of Private Label Products: An Empirical Research. Journal of Competitiveness, 10(3), 149-163. http://doi.org/10.7441/joc.2018.03.10
Lucia Svabova, (RNDr., PhD) is an Assistant Professor at the Department of Economics, Faculty of Operation and Economics of Transport and Communications, University of Zilina (Slovak Republic). Research interests: statistics, econometrics, multivariate statistical methods, counterfactual impact evaluation, financial derivatives.

Katarina Valaskova, (Ing., $\mathrm{PhD}$ ) is an Assistant Professor at the Department of Economics, Faculty of Operation and Economics of Transport and Communications, University of Zilina (Slovak Republic). Research interests: financial and investment management, consumer policy and artificial intelligence such as fuzzy logic, neural networks.

Pavol Durana, (Ing., PhD) is an Assistant Professor at the Department of Economics, Faculty of Operation and Economics of Transport and Communications, University of Zilina (Slovak Republic). Research interests: quality, management, economic applications of statistics.

Tomas Kliestik, (prof., Ing., PhD) head of the Department of Economics, Faculty of Operation and Economics of Transport and Communications, University of Zilina (Slovak Republic). Scientific activities: scientific monographs, professional publications, books, more than 220 national and international contributions in journals and conferences. Research interests: financial management, credit risk, econometric modelling. 